\section{Neuroradiology: The Requisites, 2nd ed.}

edited by Robert Grossman and David Yousem, 908 pp., ill., Philadelphia, Mosby, 2003, $\$ 99$

The last couple of decades have witnessed an explosion in brain imaging techniques. This second edition of Neuroradiology: The Requisites by Robert Grossman and David Yousem builds upon and subsequently expands the foundation initially laid in the first edition published in 1984. Like its predecessor this edition will also be widely accepted as one of the standard textbooks in neuroradiology in the year to come.

This 908-page book is divided into 18 chapters. Chapters within this book cover topics such as neoplasms, head trauma, mucosal disease, and degenerative diseases of the spine. Each chapter begins with a comprehensive list of the contents within that chapter and it is quite easy to find particular subjects that are covered. Also, within each chapter there are excellent, extremely clear quality characteristic scans of particular disease processes. Numerous tables and boxes can also be found within each chapter. These figures are excellent for quick review of particular high yield information and summarize important information.

Overall, this is an engaging book that is constantly filled with the humor of the two authors. It is particularly easy to read and difficult neuroimaging concepts are covered with great aplomb by these authors. Of special note are the first and last chapters of this book. They are a must read for any clinician (especially neurology residents and fellows) at any stage of learning. Within the first chapter each of the most common imaging techniques is reviewed with basic physiology as well clinical applications stressed. The last chapter provides an excellent framework to interpret scans and may be a lifesaver for many residents on call. The index is quite complete and allows for quick reference to particular topics.

This is an excellent, well-organized, highly entertaining textbook. Even though it is a little expensive, it should be on the bookshelf of all neurology residents no matter what field they eventually pursue. It is a comprehensive textbook that will provide invaluable assistance not only during a neuroradiology rotation but also for future board examinations and recertification tests. It is hoped that the authors will continue to update this masterpiece in the years to come.

Beau M. Ances, MD, PhD

Copyright @ 2005 by AAN Enterprises, Inc. 


\title{
Neurology
}

\author{
Neuroradiology: The Requisites, 2nd ed. \\ Beau M. Ances \\ Neurology 2005;64;E16 \\ DOI 10.1212/WNL.64.2.E16
}

This information is current as of January 24, 2005

\section{Updated Information \&}

Services

Permissions \& Licensing

Reprints including high resolution figures, can be found at: http://n.neurology.org/content/64/2/E16.full

Information about reproducing this article in parts (figures,tables) or in its entirety can be found online at:

http://www.neurology.org/about/about_the_journal\#permissions

Information about ordering reprints can be found online:

http://n.neurology.org/subscribers/advertise

Neurology ${ }^{\circledR}$ is the official journal of the American Academy of Neurology. Published continuously since 1951, it is now a weekly with 48 issues per year. Copyright. All rights reserved. Print ISSN: 0028-3878. Online ISSN: 1526-632X.

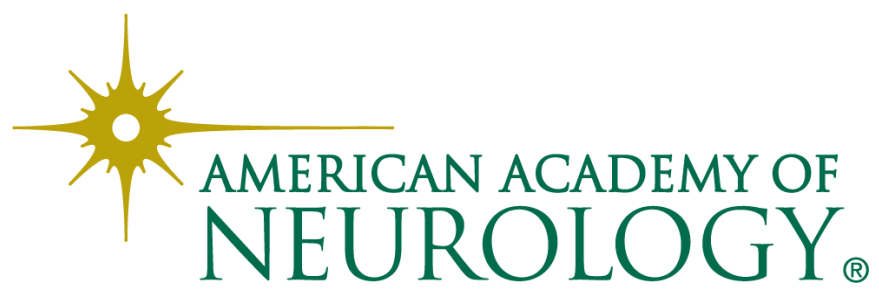

